\title{
THE DESIGN OF RECORDS FOR FIELD WORK
}

\author{
BY \\ LANCELOT HOGBEN and K. W. CROSS \\ From the Department of Medical Statistics, University of Birmingham
}

There is little doubt that large numbers of physicians and medical officers could usefully collaborate in a great variety of large-scale inquiries of no mean importance, if research workers themselves were more fully aware of the need for designing records with due regard to certain principles which the medical curriculum does not as yet accommodate. Current supervision of case notes in medical instruction and current methods of completing them in almost all hospitals still adhere to a traditionally narrative pattern, entrusting the observer to use his or her own discretion about what to record or when to record it. Even when the topic of interest is the single individual, as in a type of inquiry recently discussed by Hogben and Sim (1953), the wastage of information by reliance on the narrative record may be enormous; but it is inevitably so if we seek to pool information about different individuals and from different sources. If the record then contains no reference to a particular attribute (A) of a particular individual, we have no certain clue to which of three possibilities is correct:

(a) the individual was not- $A$;

(b) the individual was $\mathrm{A}$, but the observer did not deem the fact to be worth recording;

(c) the individual was $A$, but the observer forgot to mention it in the case summary.

One example from published work (Hogben, Worrall, and Zieve, 1932) on the genetic basis of alcaptonuria will make this clear. Available records of individuals with this condition disclosed the following results referable to 45 fraternities containing in all 125 sibs:

\begin{tabular}{|c|c|c|}
\hline Relationship of Parents & Fraternities & Alcaptonurics \\
\hline 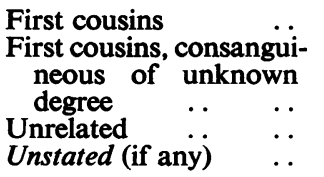 & $\begin{array}{r}12 \\
1 \\
20 \\
12\end{array}$ & $\begin{array}{r}1 \\
36 \\
20\end{array}$ \\
\hline Total .. & 45 & 83 \\
\hline
\end{tabular}

If we confine our attention to individuals concerning whose parentage we have definite information, the sample percentage of alcaptonurics with consanguineous parents is therefore 42 . If we assume that parents are not consanguineous unless otherwise stated, the percentage is 24.4 ; and there are good enough theoretical reasons for being well-nigh certain that the lower figure is correct. Thus the alcaptonurics illustrate the truism that writers of case histories in essay form are prone to record information only if it seems to call for special comment. Unless records explicitly call for information, what information they do supply is of little, if any, value.

This is true of almost any medical investigation which takes within its scope records of different individuals and observations on different occasions; but it is still more true when observers with different standards of what is important collaborate, especially when the designation of one and the same sign or symptom involves an act of interpretation. Thus a preliminary desideratum of such investigation is a proforma which contains no terms other than those which are verbally definable by general admission and otherwise explicitly in the context, or are valid in the sense that they conform to the criterion of the identity parade. In truth, ambiguity may arise at a much more elementary level. Thus the item "(1) married; (2) not married", set out as an exclusive $A$ or not- $A$ attribute in a niche for the marital status of the individual, leaves the observer free to place a divorced person in either category, unless the words as yet or hitherto follow the negative particle.

What is less widely recognized is that each such niche of the observational record should also be statistically* unambiguous in the sense that the attributes it accommodates constitute an exclusive and exhaustive set in the sense that:

(a) no more than one attribute of the set specified can pertain to one and the same individual;

(b) every individual is specifiable by one such attribute.

Interpreted literally, the last requirement is a council of perfection, but we can satisfy the requirements of an exclusive-exhaustive taxonomy by the *In speaking of a taxonomic specification as statistically unambiguous
if exhaustive and exclusive as here defined, we do so because repeated
enumeration till totals agree is highly wasteful. If the classification is
exhaustive, the total recorded for any niche will be the size of sample,
and if exclusive the sum of the enumerated subsets indicated by the
code numbers for the several rows will be equivalent thereto. We
then have a double check on the reliability of the enumeration without recourse to repetition. 
device of the open cell: other-unspecified-doubtful. Bacon remarks that nature is more diverse in her operations than is man in his conceptions; and it is indeed prudent to employ the open-cell even if disposed to believe both that the nomenclature is unequivocal and that it covers all contingencies. Two items in an obstetrical record designed by the Department of Medical Statistics sufficiently illustrate its use (16 and 17 at foot of page).

Here Item 16 is exhaustive in the sense that it allows for a positive, negative or doubtful test and for no test at all. As it stands, it is not exclusive unless we also know (as we did) that:

(a) an individual if tested would have submitted to one only of the three tests specified;

(b) no other laboratory test was in use at the time.

Such then are the elementary desiderata of a record for research involving observations on different individuals or even (Hogben and Sim, 1953) on the same individual, more especially if different observers collaborate; and one may hazard the opinion that medical students would get a better training in the art of observation and in medical semantics, if required to complete a predesigned record appropriate to the type of case instead of relying on individual judgment set out in narrative. Be that as it may, the art of designing the best form such a record may take is one which comes by long experience only, in the absence of any texts which fully discuss the issues involved. Hence the hope that what follows will be of service to research workers in medicine.

The choice of words and categories referred to in the foregoing remarks is by no means always an easy intellectual exercise; nor is the need for it selfevident. What makes the need for a statement of principles more pressing is that clarity is not enough.
It does not suffice to ensure that we shall record all the information we require and that we have no doubts about the meaning of what we have recorded. Other desiderata of the design of the record are the possibility of rendition and of extracting the data for analysis with minimal effort. If the investigation subsumes a very large number of records, the lastnamed requirement implies suitability for enlisting mechanical devices for sorting or tabulation. Even when the records are relatively few, it will be possible to delegate the task of extracting the data for tabulation to a clerical assistant with confidence only if it is also possible to formulate instructions for a hand-sort in terms which require no technical acquaintance with the topic.

A layout which permits the fullest use of mechanical aids is equally suitable for a hand-sort by a clerical assistant. Mechanical aids first came into use for enumeration, costing, and tabulating information which is largely numerical, as in accountancy. If the data of a record are qualitative, it will be possible to feed the information to the machine only if translated into its own language, i.e. a numerical code. The salesman's view, encouraged by experience of accountacy, the totalizator, and market research, is that the bottleneck of mechanical aids is the operation of punching and verifying. We have listened to many discussions on the value of photo-electric devices for eliminating the punchcard, and have no doubt that one or other will come into general use eventually; but the effort expended and the liability to error incurred in conveying coded information to a punch-card is trivial in comparison with the problem of translating highly-specialized information involving an immense vocabulary of technical terms into a code. If we are to make the fullest use of case history material, we must find

\begin{tabular}{|c|c|c|c|c|c|c|c|c|c|c|c|c|}
\hline \multirow{2}{*}{\multicolumn{2}{|c|}{$\begin{array}{c}\text { Col. No. } 16 . \\
\text { Pregnancy } \\
\text { Diagnosis Test } \\
\text { Performed } \\
\end{array}$}} & \multirow{2}{*}{ None } & \multicolumn{3}{|c|}{ Aschheim-Zondek } & \multicolumn{4}{|c|}{ Friedmann } & \multicolumn{3}{|c|}{ Hogben } \\
\hline & & & Positive & Negative & Doubtful & Positive & $\mathrm{Ne}$ & gative & Doubtful 1 & Positive & Negative & Doubtful \\
\hline \multicolumn{2}{|c|}{ Code (row) } & 0 & 1 & 2 & 3 & 4 & & 5 & 6 & 7 & 8 & 9 \\
\hline $\begin{array}{c}\text { Col. No. } \\
17 . \\
\text { Ante- } \\
\text { Natal } \\
\text { Care }\end{array}$ & None & $\begin{array}{c}\text { Hospital } \\
\text { Out- } \\
\text { Patient } \\
\text { Depart- } \\
\text { ment }\end{array}$ & $\begin{array}{c}\text { Private } \\
\text { Prac- } \\
\text { titioner }\end{array}$ & \multicolumn{2}{|c|}{$\begin{array}{l}\text { Hospital Out- } \\
\text { Patient Depart- } \\
\text { ment and Private } \\
\text { Practitioner }\end{array}$} & \multicolumn{2}{|c|}{$\begin{array}{c}\text { Corpora- } \\
\text { tion Ante- } \\
\text { Natal Clinic }\end{array}$} & \multicolumn{2}{|c|}{$\begin{array}{l}\text { Corporation } \\
\text { Ante-Natal } \\
\text { Clinic and Pri- } \\
\text { vate Practitioner }\end{array}$} & \multicolumn{2}{|c|}{$\begin{array}{c}\text { Corporation } \\
\text { Ante-Natal } \\
\text { Clinic and Hos- } \\
\text { pital Out-Patient } \\
\text { Department }\end{array}$} & $\begin{array}{c}\text { Other } \\
\text { (specify) }\end{array}$ \\
\hline $\begin{array}{l}\text { Code } \\
\text { (row) }\end{array}$ & $\mathbf{0}$ & 1 & 2 & \multicolumn{2}{|c|}{3} & \multicolumn{2}{|l|}{4} & \multicolumn{2}{|r|}{5} & & 6 & 9 \\
\hline
\end{tabular}


some means of coding at source. By coding at source, we mean that the expert observer must be his own translator.

In what follows we may assume that the machine operates with punched cards, and that the layout of the observational record suffices to give all the necessary instructions to the operator responsible for punching. Accordingly, it will show on the lefthand margin of each niche the column or columns which accommodate the corresponding items of information and on the right-hand a box to accommodate the specification of the appropriate row to punch. As stated, no problem of translation arises when the information is intrinsically numerical:

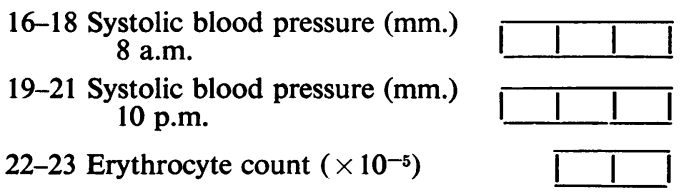

Here it suffices to insert the relevant numbers in the box. For instance, a red blood count of $3,700,000$ will appear as $|3| 7 \mid$, signifying that the punchcard operator punches Row 3 in Col. 22 and Row 7 in Col. 23. Similarly, a red blood count of 900,000 will appear as $0|9|$.

We may here assume that we use ten rows per column, labelled $0-9$, in the simplest way. Only one hole will then appear on any column of the punchcard. By use of additional $X$ and $Y$ rows, a column can in fact accommodate any one of more than ten units of information, and some machines interpret more than one hole per column; but the investigator who is not au fait with the subtleties of the machine's performance will be wise to follow a plan which-if less economical than it need be-is easy to understand and to interpret when the time comes to issue appropriate instructions for sorting and tabulating the information which the machine can digest.

Much information can be explicitly coded by recourse to an instruction to ring or tick the appropriate item as illustrated by (15) the second item of a record for cases of cerebral thrombosis:

$$
\begin{array}{r}
\text { 13-14 Duration of Stay (days) } \\
01 \text { to } 99 \text { (= } 99 \text { or more) }
\end{array}
$$

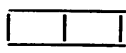

\begin{tabular}{|c|c|c|c|c|c|}
\hline \multicolumn{2}{|c|}{ Speech Normal } & \multicolumn{2}{|c|}{ Speech Defective } & \multicolumn{2}{|c|}{$\begin{array}{l}\text { Aphasia without } \\
\text { Comprehension }\end{array}$} \\
\hline $\begin{array}{c}\text { B.P. } \\
\text { Normal }\end{array}$ & $\begin{array}{l}\text { Hyper- } \\
\text { tensive }\end{array}$ & $\begin{array}{c}\text { B.P. } \\
\text { Normal }\end{array}$ & $\begin{array}{l}\text { Hyper- } \\
\text { tensive }\end{array}$ & $\begin{array}{c}\text { B.P. } \\
\text { Normal }\end{array}$ & $\begin{array}{l}\text { Hyper- } \\
\text { tensive }\end{array}$ \\
\hline $\mathbf{0}$ & 1 & 2 & 3 & 4 & 5 \\
\hline
\end{tabular}

15 Initial Speech
In contradistinction to self-coding, as illustrated by the above, we must sometimes rely on coding by reference, in which event it is wise to give the appropriate verbal specification below, leaving completion of the document by recourse to the code till the observational record is otherwise complete. For instance, we may lay out diagnosis as below by recourse to the W.H.O. list of diseases:

\section{Diagnosis (Code K). Specify ...........}

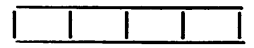

There are unfortunately few such codes available for use, and of these some are too bulky or open to objection on other grounds. For England and Wales, the official Industry Code would be adequate as it stands if the employed person could produce any document disclosing his or her code specification. Actually, the employer retains the only document on which this specification appears. This dilemma calls for official intervention at a high level, pending which we cannot use it to code industry. Unlike the official code of industries, the Ministry of Labour numbered list of occupations is too vast for Record Office use and is ill-adapted to the requirements of occupational medicine without translation into a secondary code based on taxonomical categories relevant to the end in view. Accordingly, it may be preferable to use an ad hoc code specifying medically relevant conditions of work (e.g. sedentary, nocturnal, outdoor, migratory), responsibility, and training, in contradistinction to explicit denomination of the patient's job.

As an example of such a layout for a miniature code with appropriate instructions for the benefit of the user, we have recommended the following:

\section{Occupation}

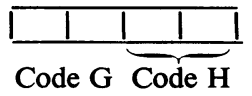

\section{Employment Status (Code G)}

To operate Code $G$ first ask whether the patient is an employee, and check answer if Yes by asking name of employer(s). Then place in 41-57 by appropriate questions. Be careful to distinguish clerical in 41-57 by appropriate questions. Be careful to distinguish clerical work (including responsible secretarial posts and qualified accountants). If the answer to the first question is No, the only difficulty which calls for comment is the distinction between the man or woman on his own (self-employed) and the employer. A shop-proprietor or farmer who has help from a relative or relatives not registered employee(s) for National Insurance is in this context self-employed.

\section{No Occupation:}

Independent means (other than savings or pension

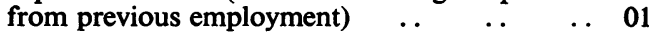

$\begin{array}{llllllll}\text { Retired } & \ldots & \ldots & \ldots & \ldots & \ldots & \ldots & 02\end{array}$ Housewife or homeworker (not in receipt of wage

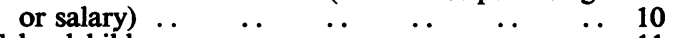

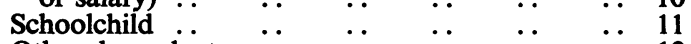

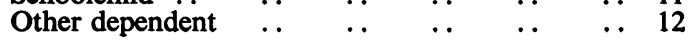


Self-Employed:

$\begin{array}{lllll}\text { Profession (private practice) } & \ldots & \ldots & \ldots & 11\end{array}$

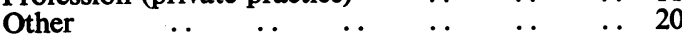

Employer (owner or partner) $\quad$. $\quad$. $\quad$. $\quad$. 30

Employee:

Managerial or Administrative (executive grade). . 41

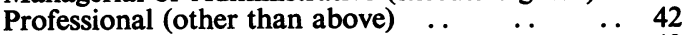

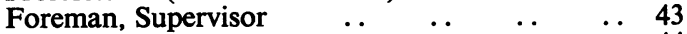

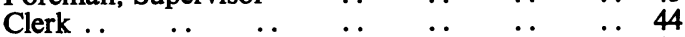

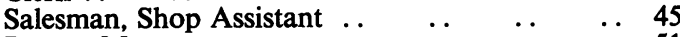

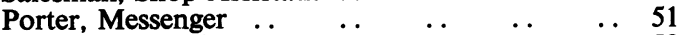

Domestic, Resident .. $\quad$.. $\quad$.. $\quad \ldots \quad$.. 52

Domestic, Non-resident (cleaners, canteen,

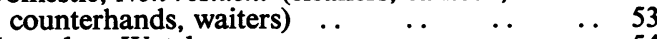

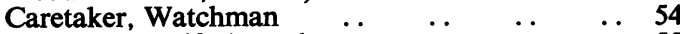

$\begin{array}{lllll}\text { Car Park or Lift Attendant } & \ldots & \ldots & \ldots & 55\end{array}$

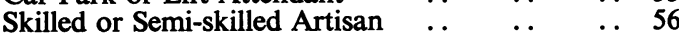

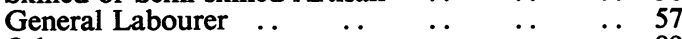

$\begin{array}{llllllll}\text { Other .. } & . & \ldots & . & . & & & \\ \end{array}$

$\begin{array}{llllllll}\text { Unspecified } & \ldots & \ldots & \ldots & \ldots & \ldots & \ldots & 99\end{array}$

\section{Place of Work (Code $\mathrm{H}$ )}

To operate Code $\mathbf{H}$ it is necessary to be clear about the distinction between $\mathrm{B}$ (temporary) and C (mobile). A person whose place of work is temporary $(B)$ here signifies one who habitually changes his place of work (plumber, interior-decorator, jobbing gardener, gas-fitter, pianotuner. A person whose work is mobile is one who is continually on the move (postman, milkman, messenger, engine-driver, bargee, busconductor. Code commercial travellers as Temporary (mixed) 40 . If in doubt, code as 99.

\section{A. Fixed}

$\begin{array}{lllllll}\text { Private Dwelling } & . & \ldots & \ldots & \ldots & \ldots & 11\end{array}$

Factory or Workshop (other than 22 ) $\quad \ldots \quad$..

$\begin{array}{lllllll}\text { Repair Shop } & \text {. } & \text {. } & \text {. } & \text {. } & \text {.. } & 22\end{array}$

$\begin{array}{lllll}\text { Retail Shop or Showroom } & \ldots & \ldots & \ldots & 23\end{array}$

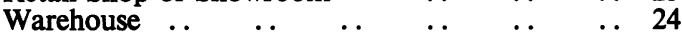

$\begin{array}{llllllll}\text { Office } & . & \ldots & \ldots & \ldots & \ldots & \ldots & 25\end{array}$

Canteen, Restaurant, Hotel $\quad \ldots . \quad \ldots . \quad \ldots 26$

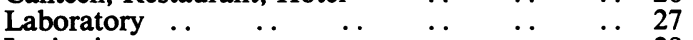

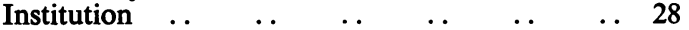

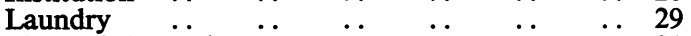

$\begin{array}{llllll}\text { Place of Entertainment } & \ldots & \ldots & \ldots & \ldots & 31\end{array}$

$\begin{array}{llllllll}\text { Mine } & \ldots & \ldots & \ldots & \ldots & \ldots & \ldots & 32\end{array}$

Lines of Communication, above ground (Stations,

Depots, Signal Box, Railway Yards, Docks, etc.) 33

Lines of Communication, below ground $\quad$. 34

$\begin{array}{lllll}\text { Outdoor (other than above). } & \ldots & \ldots & \ldots & 35\end{array}$

$\begin{array}{llllllll}\begin{array}{c}\text { B. Temporary } \\ \text { Indoor }\end{array} & \ldots & \ldots & \ldots & \ldots & \ldots & \ldots & 41 \\ \text { Outdoor } & \ldots & . & . & . & \ldots & \ldots & 42 \\ \text { Mixed } & . & . & \ldots & \ldots & \ldots & \ldots & 40\end{array}$

C. Mobile

$\begin{array}{lllllll}\text { On foot } \text { or cycle } & . & \ldots & \ldots & \ldots & \ldots & 51\end{array}$

$\begin{array}{llllll}\text { Vehicle above ground } & . & \ldots & \ldots & \ldots & 51 \\ & & . & . . & . & 52\end{array}$

$\begin{array}{llllll}\text { Vehicle below ground } & \ldots & \ldots & \ldots & \ldots & 53\end{array}$

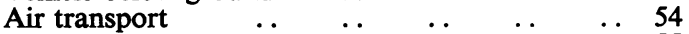

$\begin{array}{lllllll}\text { Water transport } & . & \ldots & \ldots & \ldots & \ldots & 55\end{array}$

$\begin{array}{llllllll}\text { D. Other } & \ldots & \ldots & \ldots & \ldots & \ldots & \ldots & 89\end{array}$

$\begin{array}{lllllll}\text { E. Unspecified .. } & \text {. } & \text {. } & \text {. } & \text {. } & \text {. } & 99\end{array}$
Locality is another headache, partly because of the diversity of area specifications (e.g. local government, food, electricity and gas, parliamentary) relevant to different administrative or other ends in view, and partly because many patients can supply no definite domiciliary information other than street and house number. At one time or another, one may need to know the educational authority responsible for a child, the accident hospital nearest to the home, the reservoir which provides its water supply. An address does not necessarily supply the information, since houses on opposite sides of a street may be in different county boroughs with a different water supply and a different educational budget. A grid is unworkable for the same reason; and much which would be of value to research (e.g. in connexion with blood-group donor distributions) will not be available on medical documents until the Post Office, Ministry of Town and Country Planning, and Ministry of Local Government get together to work out a national code for domiciliary specification. Meanwhile, as a pis aller, we ourselves use a code of our own based on the Local Food Office as stated on the patient's ration card. We should like to commend to the consideration of the Central Statistical Office the setting up of a National Co-ordination Committee on domiciliary, occupational, and industrial aspects of the coding problem.

Aside from the specialist knowledge which the construction of appropriate codes entails, the task is not one to dismiss lightly. Any sequence of numbers like those of the telephone directory will, of course, satisfy the requirements of a punch-card system, if the only end in view is to feed the information to the machine; but the proper design of a code should make the food digestible. As far as is practicable, this means that every cipher allocated to a column should be referable to some unique level of a taxonomical hierarchy. It is then possible to extract information of a particular type by a sort based on one column alone. For example, the 3-cipher sequence 001 to 456 suffices to accommodate all the 456 medical units (hospitals, clinics, sanatoria, convalescent homes, mental institutions, and colonies) of a particular region; but administrative requirements of one kind or another may call for information referable to medical units of a "Group" under the Act, to medical units situated within the boundaries of a particular unit of local government, to medical units with a particular type of accommodation (e.g. casualty department, beds for mental cases), and so forth. A 4-cipher or 5-cipher sequence for a designation otherwise adequately accommodated by three columns may therefore greatly assist us to coax the machine to deliver the data we want. 
Two other considerations call for comment when it is necessary to call in an ad hoc code. One is that it may be possible to economize column space by incorporating information of more than one type in the same niche, as for instance sex and date of birth in the Personnel Specification Code of Hogben, Johnstone, and Cross (1948). The other issue worth mentioning is that a code for general use should be foolproof for the user, with respect both to explicit specification of the attribute and to its niche (column number or numbers) in the record. The following entry in the Midland Region Medical Codes of the United Birmingham Hospitals illustrates both desiderata. As for the foregoing occupation code the precise form of the column specification in the record itself appears above the instructions for coding:

\section{Patient's Birth Rank (Code J)}

Note.-If the individual is one of a pair of live-born twins or one of triplets, etc., it may not be possible to ascertain the actual order of triplets, etc., it may not be possible to ascertain the actual order of delivery. When (and only when) unable to do so, count as the elder
the one whose first name comes first alphabetically (e.g. Martha before Mary, and Jack before James).

$\begin{array}{ccc}\text { Question } & \text { Answer Code No. } \\ \text { Are you the first born child of } & \text { I don't know } 0 \\ \text { your mother? } & \text { Yes } & 1 \\ \text { No } & \text { (see below) }\end{array}$

How many live-born children, living or deceased, had your mother before your birth?

$\begin{array}{cc}\text { I don't know } & 0 \\ \text { One } & 2 \\ \text { Two } & 3 \\ \text { Three } & 4 \\ \text { Four } & 5 \\ \text { Five } & 6 \\ \text { Six } & 7 \\ \text { Seven } & 8 \\ \text { Over Seven } & 9\end{array}$

A department which has constant use for recording data of a particular class may find the labour of preparing ad hoc codes worth while; but it is not a task to undertake lightly. A third approach to the problem of coding economically is therefore worthy of consideration. Where the record calls for the specification of cognate attributes, it may be possible and it is most straightforward to work with simple dichotomies and trichotomies laid out hierarchically as in the foregoing illustrations from an Obstetric Record. There is, however, a procedure which involves no difficulty and is, as far as we know, novel. Consider the following situation. The psychiatric field-worker wishes to record the patient's demeanour in an interview under the headings:

A. insolent, B. aloof, C. excited, D. ingratiating, E. angry, F. listless, G. impatient, H. restless, J. normal.

It goes without saying that this is not an exhaustive and exclusive classification, since a person may be insolent, angry, and excited in the same context. In fact the $\boldsymbol{n}$ attributes we are looking for in a given context may be such that an individual may have $0,1,2,3 \ldots$ or $n$ of them. We can, of course, regard each with its opposite and doubtful as one item of an exhaustive exclusive set of three; but it would then be wasteful of column space to allocate one column to each. On the other hand, the entire assemblage constitutes an exhaustive and exclusive set of enumerable combinations, viz:

$$
{ }^{n} \mathrm{C}_{0}+{ }^{n} \mathrm{C}_{1}+{ }^{n} \mathrm{C}_{2} \ldots \ldots+{ }^{n} \mathrm{C}_{n}=(1+1)^{n}=2^{n}
$$

Thus there will be at most 64 items of an exhaustive exclusive set of six attributes, and at most 512 of nine attributes, and 8,192 of thirteen attributes. This means that one 2-column code will suffice for five or six attributes, one 3-column code for seven, eight, or nine attributes, and one 4-column code for ten, eleven, twelve, or thirteen attributes. Thus we may lay out the appropriate record for the situation envisaged above for three consecutive columns (here 17-19):

\section{7-19 Patient's Demeanour (Ring appropriate letters)}

$\begin{array}{lll}\mathbf{A} \text { insolent } & \text { D ingratiating } & \text { G impatient } \\ \mathbf{B} \text { aloof } & \text { E angry } & \text { H restless } \\ \text { C excited } & \text { F listless } & \text { J normal }\end{array}$

The most simple plan for the construction of such a code is as follows for, say, five attributes A-E:

\begin{tabular}{|c|c|c|c|c|c|c|c|c|}
\hline None & & 00 & BC & only & 10 & BCD & only & 22 \\
\hline A & only & 01 & BD & " & 11 & BCE & $"$ & 23 \\
\hline B & 0 & 02 & BE & ," & 12 & BDE & , & 24 \\
\hline C & & 03 & $C D$ & " & 13 & $\mathrm{CDE}$ & " & 25 \\
\hline D & , & 04 & CE & ," & 14 & $\mathrm{ABCD}$ & 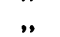 & 26 \\
\hline $\mathrm{E}$ & " & 05 & $\mathrm{DE}$ & ," & 15 & $\mathrm{ABCE}$ & .. & 27 \\
\hline AB & , & 06 & $\mathrm{ABC}$ & " & 16 & $\mathrm{ABDE}$ & " & 8 \\
\hline AC & " & 07 & ABD & $"$ & 17 & ACDE & ", & 9 \\
\hline AD & ", & 08 & ABE & ," & 18 & BCDE & & 30 \\
\hline $\mathrm{AE}$ & 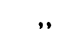 & 09 & ACD & ," & 19 & ABCDE & E, & 31 \\
\hline & & & ACE & $"$ & 20 & & & \\
\hline & & & ADE & 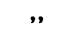 & 21 & & & \\
\hline
\end{tabular}

The instructions for the sort whether by hand or machine will then be:

None 00

all $\mathrm{A}$ 01, 06-09, 16-21, 26-29, 31

all B 02, 06, 10-12, 16-18, 22-24, 26-28, 30-31, etc.

all $\mathrm{AB}$ 06, 16-18, 26-28, 31 all $\mathrm{ABC}$ 16, 26-27, 31

all DE 15, 21, 24-25, 28-31 all BCD 22, 26, 30-31 etc. etc.

all $\mathrm{ABCD} 26,31$

all $\mathrm{BCDE}$ 30-31, etc. 
If the combinations and code numbers are laid out according to the foregoing sequential plan it is easy to check the list.

Let $\mathrm{S}_{r}=\left({ }^{n} \mathrm{C}_{0}+{ }^{n} \mathrm{C}_{1}+{ }^{n} \mathrm{C}_{2} \ldots{ }^{n} \mathrm{C}_{r}\right)$.

Then we shall assign:

None 0; Singles $\mathrm{S}_{0} \ldots\left(\mathrm{S}_{1}-1\right) ;$ Doubles $\mathrm{S}_{1} \ldots\left(\mathrm{S}_{2}-1\right)$

and generally for $r$-fold combinations from

$$
S_{r-1} \ldots\left(S_{r}-1\right) \text {. }
$$

Such a code embraces a taxonomy which is exclusive and exhaustive, allowing for the possibility that an individual might have none of the attributes A-E or that he might have all of them. Since the specification of the meaning of $A, B \ldots$ etc. is explicit on the record, one code like the above will suffice for any set of $\boldsymbol{n}$ attributes, regardless of their designation in a particular niche. Hence we may speak of a code of this type as a universal code.
This does not mean that it overrides the need for an ad hoc code when the number of attributes is larger than, say, three. Its special usefulness will be for situations in which a set of cognate attributes is neither exclusive nor exhaustive. For the convenience of others we here append two codes, one for five or six attributes, and one for seven, eight, or nine attributes. We have prepared for use a 4-column code for ten to thirteen attributes, but it is too bulky to include here.

For samples of complete pre-designed medical documents, we refer the reader to the recent publication of Hogben and Sim (1953).

\section{REFERENCES}

Hogben, L. (1951). Incorporated Statistician, 2, No. 2, p. 2. 149 and Cross, K. W. (1948). British Journal of Social Medicine, 2, 149 .

- Johnstone, M. M., and Cross, K. W. (1948). Brit. med. J., 1, 632. - and Sim, M. (1953). British Journal of Preventive and Social Medicine, 7, 163. 264. Worrall, R. L., and Zieve, I. (1932). Proc. Roy. Soc. Edinb., 52,

APPENDIX

CODE I

\section{Attributes: ABCDEF}

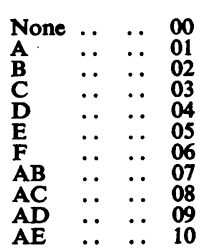

$\begin{array}{llll}\text { ABC } & \ldots & \ldots & \mathbf{2 2} \\ \text { ABD } & \ldots & \ldots & \mathbf{2 3} \\ \text { ABE } & \ldots & \ldots & \mathbf{2 4} \\ \text { ABF } & \ldots & \ldots & \mathbf{2 5} \\ \text { ACD } & \ldots & \ldots & \mathbf{2 6} \\ \text { ACE } & \ldots & \ldots & \mathbf{2 7} \\ \text { ACF } & \ldots & \ldots & \mathbf{2 8} \\ \text { ADE } & \ldots & \ldots & \mathbf{2 9} \\ \text { ADF } & \ldots & \ldots & 30 \\ \text { AEF } & \ldots & \ldots & \mathbf{3 1} \\ \text { BCD } & \ldots & \ldots & 32\end{array}$

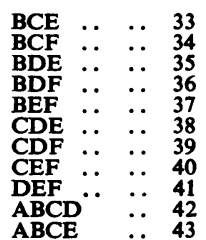

CoDE II

Attributes: ABCDEFLMN

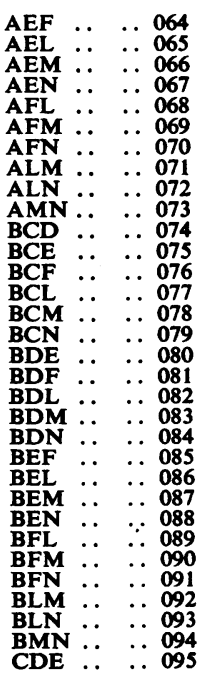

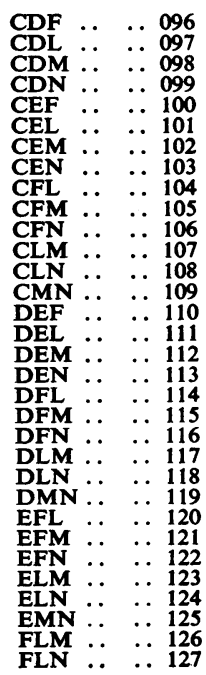

$\begin{array}{lll}\text { ABCF } & \ldots & \mathbf{4 4} \\ \text { ABDE } & \ldots & \mathbf{4 5} \\ \text { ABDF } & \ldots & 46 \\ \text { ABEF } & \ldots & \mathbf{4 7} \\ \text { ACDE } & \ldots & \mathbf{4 8} \\ \text { ACDF } & \ldots & 49 \\ \text { ACEF } & \ldots & 50 \\ \text { ADEF } & \ldots & 51 \\ \text { BCDE. . } & \ldots & 52 \\ \text { BCDF. . } & \ldots & 53 \\ \text { BCEF } & \ldots & 54\end{array}$

$\begin{array}{lll}\text { BDEF } & \ldots & 55 \\ \text { CDEF.. } & \ldots & 56 \\ \text { ABCDE } & \ldots & 57 \\ \text { ABCDF } & \ldots & 58 \\ \text { ABCEF } & \ldots & 59 \\ \text { ABDEF } & \ldots & 60 \\ \text { ACDEF } & \ldots & 61 \\ \text { BCDEF } & \ldots & 62 \\ \text { ABCDEF } & \ldots & 63\end{array}$

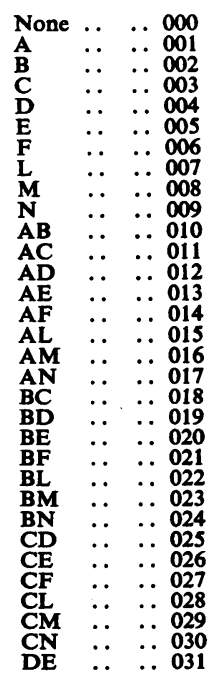

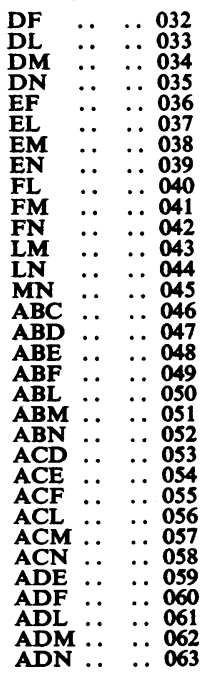

$\begin{array}{lll}\text { FMN } \ldots & \ldots & 128 \\ \text { LMN } & \ldots & 129 \\ \text { ABCD } & \ldots & 130 \\ \text { ABCE } & \ldots & 131 \\ \text { ABCF } & \ldots & 132 \\ \text { ABCL } & \ldots & 133 \\ \text { ABCM } & \ldots & 134 \\ \text { ABCN } & \ldots & 135 \\ \text { ABDE } & \ldots & 136 \\ \text { ABDF } & \ldots & 137 \\ \text { ABDL } & \ldots & 138 \\ \text { ABDM } & \ldots & 139 \\ \text { ABDN } & \ldots & 140 \\ \text { ABEF } & \ldots & 141 \\ \text { ABEL } & \ldots & 142 \\ \text { ABEM } & \ldots & 143 \\ \text { ABEN } & \ldots & 144 \\ \text { ABFL } & \ldots & 145 \\ \text { ABFM } & \ldots & 146 \\ \text { ABFN } & \ldots & 147 \\ \text { ABLM } & \ldots & 148 \\ \text { ABLN } & \ldots & 149 \\ \text { ABMN } & \ldots & 150 \\ \text { ACDE } & \ldots & 151 \\ \text { ACDF } & \ldots & 152 \\ \text { ACDL } & \ldots & 153 \\ \text { ACDM } & \ldots & 154 \\ \text { ACDN } & \ldots & 155 \\ \text { ACEF } & \ldots & 156 \\ \text { ACEL } & \ldots & 157 \\ \text { ACEM } & \ldots & 158 \\ \text { ACEN } & \ldots & 159 \\ & \end{array}$

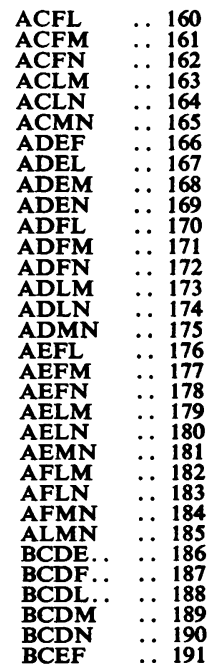




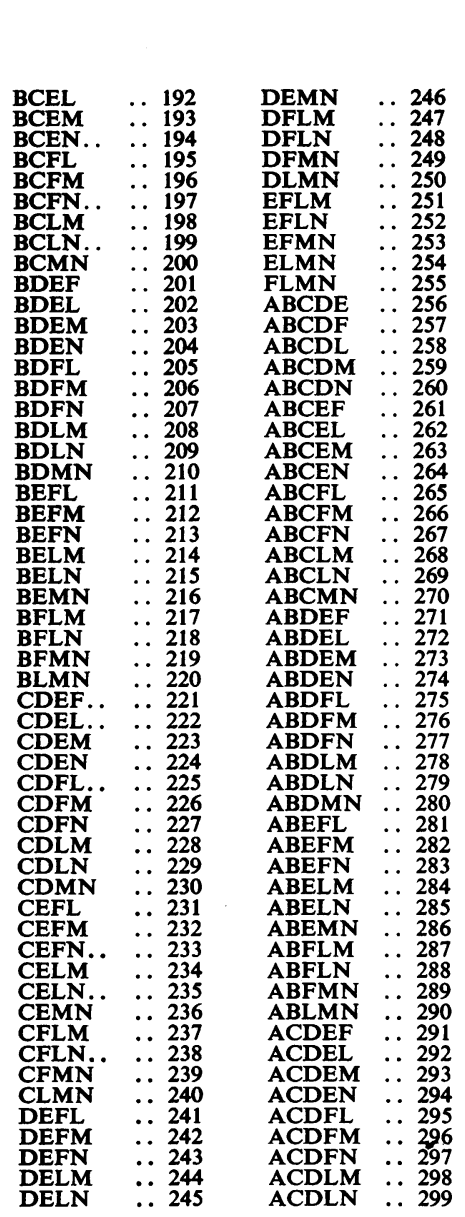

\section{APPENDIX-contd.}

CODE II-contd.

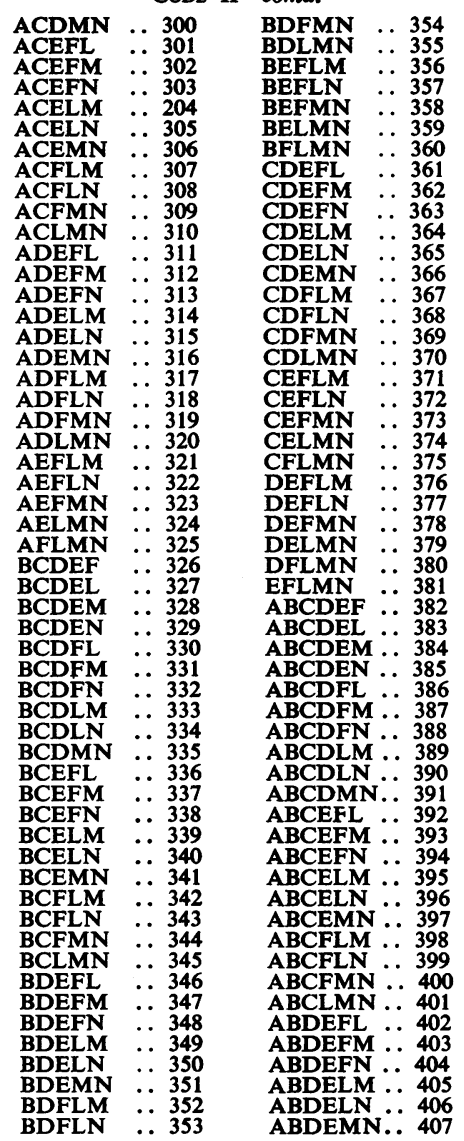

ABDFLM .. 408 ABDFLN .. 409 ABDFMN .. 410 ABDLMN .. 411 ABEFLM $\ldots 412$ ABEFMN .. 414 ABELMN .. 415 ABFLMN .. 416 ACDEFL $\ldots 417$ ACDEFM $\because 418$ ACDEFM. .4419 ACDELM . . 420 ACDELN . . 421 ACDEMN. . 422 ACDFLN . .424 ACDFMN.. 425 ACDFMN.. 425 ACEFLM . . 427 ACEFLN .428 ACEFMN .. 429 ACFLMN ‥431 ADEFLM $\because 432$ ADEFLM $\ldots 432$
ADEFLN $\ldots 433$ $\begin{array}{lll}\text { ADEFLN } & .043 \\ \text { ADEFMN } . . & 434\end{array}$ ADELMN.. 435 ADFLMN .. 436 AEFLMN .. 437 BCDEFL . . 438 BCDEFM .. 439 BCDEFN $\because 440$ BCDELM $\because 441$ BCDELM
BCDELN BCDEMN .. 443 BCDFLM .. 444 BCDFLN .. 445 BCDFMN .. 446 BCDLMN .. 447 BCEFLM . . 448 BCEFLN $\because .449$ BCEFMN .. 450 BCELMN . . 451 BCFLMN . . 452 BDEFLM .. 453 BDEFLN .. 454 BDEFMN .. 455 BDELMN .. 456 BDFLMN .. 457 CDEFLM … 459 CDEFLN .. 460

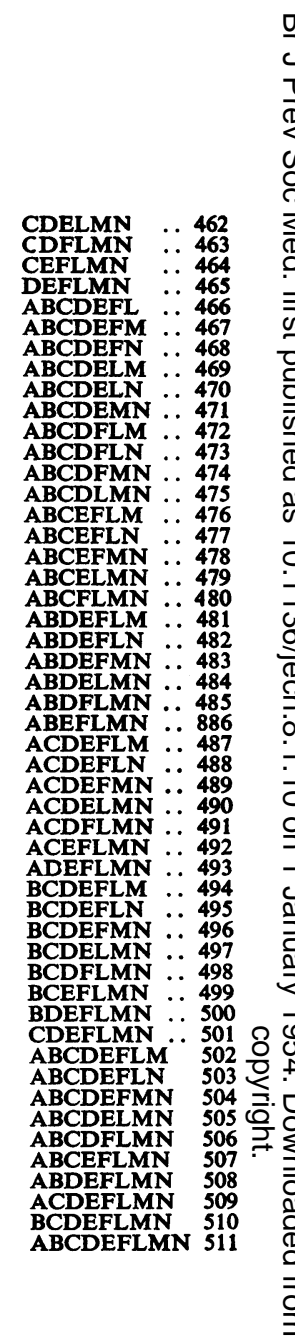

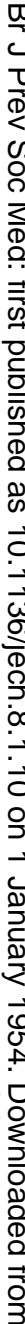

